\title{
Why Iron Brothers (Pakistan and China) Could Not Cooperate in the Film Industry
}

\author{
Zakir Ullah, Yixuan Zhu*, Abubakar Elsiddig Ahmed Elmustafa Elsheikh Hayaty, Qingwen Liu \\ School of Communication, Northwest Normal University, Lanzhou, China \\ Email: ^top_zyx@126.com
}

How to cite this paper: Ullah, Z., Zhu, Y. X., Hayaty, A. E. A. E. E., \& Liu, Q. W. (2021). Why Iron Brothers (Pakistan and China) Could Not Cooperate in the Film Industry. Advances in Journalism and Communication, 9, 114-121.

https://doi.org/10.4236/ajc.2021.93009

Received: July 4, 2021

Accepted: September 13, 2021

Published: September 16, 2021

Copyright $\odot 2021$ by author(s) and Scientific Research Publishing Inc. This work is licensed under the Creative Commons Attribution International License (CC BY 4.0).

http://creativecommons.org/licenses/by/4.0/

\begin{abstract}
In the present world of globalization, movies are the most powerful and influential medium of art. Movies can help us better understand our lives, culture, and societies of those not directly linked to us. In addition, movies shed light on political and spiritual matters and broaden our understanding, critical thinking, and feelings. Pakistan and China enjoyed more than 70 years of friendship. They cooperated in several sectors; however, there is no cooperation in the entertainment industry/film industry that might be a pivotal medium for both countries to improve their understanding. This review was aimed to find out the possible hurdles and problems that prevent Chinese movies from screening in Pakistani cinemas. Furthermore, possible suggestions are discussed that could allow the Chinese movies to screen in Pakistani cinema in the future. In this digital era, movies could play a vital role in strengthening friendship and enhancing the understanding between the two iron brothers.
\end{abstract}

\section{Keywords}

Chinese Movies, Pakistani Cinema, Pak-China Friendship, Entertainment Industry

\section{Introduction}

Xi Jinping, the president of China, once said that "Pakistan china friendship is unbreakable and as solid as a rock" (The Economic Times, 2019). Ex-president Hu Jintao described the relationship between Pakistan and China as "higher than the Himalayas, deeper than the Indian Ocean and sweeter than honey" (Address at Islamabad Convention Centre, 2006). Once, Ex-president of Pakistan, General Pervez Musharraf, mentioned that "despite changes at the regional and global levels, the deep-rooted ties between the two countries have been 
gaining strength with time" (Reuters Staff, 2008). Recently, the Chinese ambassador in Pakistan mentioned that Pakistan considers China one of its closest friends and partner, and China considers Pakistan its "Iron Brother" (Samaa Staff, 2019). The historical billions of dollars ( $\$ 62$ billion) project of the China-Pakistan Economic Corridor (CPEC) is the symbol of mutual trust between both countries (Reuters Staff, 2020). Pakistan and China successfully collaborated in several sectors, including energy, education, construction, and health. However, both countries failed to collaborate in the film industry. Pakistani film industry produces a small number of movies that are not sufficient, and the local cinema is in decline (Khan et al., 2015) and depends on imported films. In the early 90s in Pakistan, Chinese movies were telecasted on Pakistan National Television (PTV). In 2018, China provided a series of documentaries, dramas, and other television programs to the PTV and other private television channels (Nadeem, 2019). In earlier 2019, PTV World (Pakistan state-owned channel) aired the first Chinese cartoon series named "Three Drops of Blood" with English subtitles. In October 2020, a Pakistani movie “Parwaz hai Junoon” (朝翔雄心) screened in Chinese cinemas with Chinese subtitles. After watching this movie we interviewed the audience and concluded that a single movie touched the hearts of local people, and they are excited for more such films to be screened soon. Besides the language barrier, Pakistani people watch Chinese movies because of the "kung fu." And idealize the Chinese Kung fu masters such as Jackie Chan, Bruce Lee, and Jet Li. However, history shows that the exchange of film between both countries is not sufficient and lacks consistency. Pakistani cinema provides space to Hollywood and Bollywood movies then why not Chinese movies? From 2015 to 2021, 27 Hollywood and Bollywood movies screened in Pakistani cinema but none was from China (Wikipedia, 2021). This question arising in the minds is the best friend of Pakistan, and China could not promote their films in Pakistan's fertile market of entertainment.

A movie tells stories about people, expectations, visions, tasks, and fears, how they relate to others, and what activities are socially acceptable or unacceptable. Movie is a potential medium that brings individuals, societies, and even countries closer and significantly representation a culture and their problems. Movies are the vibrant medium of learning culture because it communicates on numerous angles (Champoux, 1999). We believe that the recent interaction of Chinese and Pakistani nations through belt and road initiatives could easily open doors for Chinese movies in Pakistan. Pakistan and China share a border, having a social history and mutual understanding; therefore, movies and television (TV) trade could strongly connect Pakistan and China. This review aimed to discuss the possible reasons that why China's film industry couldn't make space in $\mathrm{Pa}$ kistan. Moreover, suggestions are given that could bring both countries together to cooperate in the film industry in the near future.

\section{Importance of Film in a Society}

Film is an outstanding hot medium to study culture because the film dissemi- 
nates many angles to the mob (Champoux, 1999; Summerfield, 1993). Movies are representing the whole image of a country (Gao \& Qin, 2020). This is an essential source of information, and due to the power of audiovisual in cinema, the viewers consider themselves part of the film story. The narratives and characters in the films become a part of our daily lives. Movie develops viewers' feelings and organizes the foundation for transmitting opinions (Blasco et al., 2015). In addition, films provide an entrance to viewers to integrate into other cultures to better understand. Film is a powerful source to preserve and promote a specific culture. Modern movies have changed societies; therefore, the importance of movies could not be ignored. Being the entertainment industry, a film plays a vital role in bringing people together. Film is a hot medium of teaching viewers in their affective domain, promoting a reflective attitude, and framing the moviegoer's emotions (Blasco et al., 2015).

\section{Chinese Film Industry}

The export of movies has become a critical portion of the race of worldwide business. It can gain rich profits and improve the structure of a country-tocountry business and the productivity of a country's values and culture, which perform an essential part in shaping the Chinese universal image and building a cultural power (Rao, 2012). China film industry is the world's fastest-growing film industry; China's Box Office Revenue Surpassed RMB 20 Billion in 2020 to Become the World's Largest Movie Market exceeding the Hollywood total of $\$ 1.9$ billion, and by this national box office revenue for 2020 China film industry became the most significant movie market in the world for the first time on record (PR Newswire, 2021). Soon, the China film industry will be the largest entertainment industry globally and become the world's largest film industry. Chris Fen's statement, the author of the recent book "Feeding the Dragon," could be observed. Chris Fenton stated that "If the government starts to see that Chinese films are doing well and the box office is bouncing back without Hollywood's help-and the consumer seems to be forgetting all about U.S. movies because their blockbusters are becoming more and more entertaining-you have to ask yourself: Why wouldn't they start weaning (stopping) their public off American movies?" (Brzeski, 2020). In short, soon Chinese film industry will overtake Hollywood as well as Bollywood.

\section{Why Are Chinese Movies Not Screened in Pakistan?}

Pakistan's local market provides a suitable place for Chinese products. But, unfortunately, the same does not apply to movies. Following are the possible reasons why Chinese films couldn't make space in Pakistan.

\subsection{Promotion}

"Promotion is the voice of the company which sends out your brand's message loud and clear to the audience. Various media platforms can be used to promote 
the company and brand. When a company wants to enter a market with its product, the company has to deal with several kinds of challenges like the product already existing in the market, building trust through different business promotional activities, and making people aware of the new products. Therefore, it should be initiated to promote the development and make people aware of them. One of the primary reasons is the lack of Promotion of Chinese movies in Pakistan. There is no promotion in Pakistan for the entertainment industry, which is one of the significant financial industries in China and can get space in the Pakistani market.

\subsection{Language}

"Language and culture interdependent." Language is the crystallization of culture; culture is transmitted to language. One of the leading causes for culture discount is the dissimilarity in language. If movies are produced in other languages, dubbing, letters, or accents, the trouble of understanding may affect appreciation and could be decreased the charm of the film (Hoskins \& Finn, 1998). Language is one of the essential parts of any culture. It is how people communicate with one another, build relationships, and create a sense of community. Language is critical for the communication of culture. As a means of communicating values, beliefs, and customs, it has an important social function and fosters group identity and harmony. Another barrier is language; Pakistani people cannot understand the Chinese language, so viewers do not prefer to watch Chinese movies. Instead, they like to watch Indian or Hollywood films.

\subsection{Culture}

Culture is a well-built element of people's lives; when you are working with the people of a country and want to build a bond with the people, know their culture helps to have some perspective and understanding of their culture. Culture is the essential element in promoting the film in a foreign country. If a country has the same culture as another country, both countries will probably watch their movies. A prominent example of this is Bollywood movies and Turkish Dramas in Pakistan. Every year a lot of Indian movies are screened on Pakistani cinema and earn a rich profit, and Pakistani people are watching that movie because of cultural similarity, culture dissimilarity is also a hurdle for Chinese film in Pakistan. No doubt that Chinese culture is one of the oldest cultures in the world. Historians say that the first evidence of civilization in this nation was from over 5,000 years ago (Gao \& Qin, 2020). But Pakistan, which has the best relation with China, knows very little about Chinese culture.

\subsection{Technology}

Technology plays a significant role in the world of moviemaking, both in front and behind the camera. Therefore, many biggest blockbusters movies are the products of technical innovation, and many feature the kind of incredible future 
technology that is integral to the plot. Nowadays, the new generation prefers technology over the traditional way, and they are amused by the technology used in movies. As Liang Gao stated, "To develop and develop national films, it is important to have high-level film concepts and the most advanced film production technology" (Gao \& Qin, 2020).

\subsection{Exchange Face}

Different cultural cooperation is now frequently used in movies, and the new generation likes to watch this combo (Gao \& Qin, 2020). Such as the movie "The Great Wall," released in 2016 and produced by American, England, and Chinese production houses. The actors were from both countries; this is an example of exchanging faces in the film "The Great Wall" appealed to the people of both countries and people from all over the world and forced them to watch the movie. Same as a famous Chinese actor all over the world known as "Jackie Chan" also worked as an actor in an American-British-Chinese co-production film "The Chinaman by Stephen Leather" (Shackleton, 2018). Indian Pakistan also exchange faces in the movies for the appealing of moviegoers.

\section{Suggestions}

Based on the brief observation of Pakistan youth and moviegoers, the following recommendations will be helpful for the Chinese movie in Pakistan.

- Promotion serves to separate a business from its rivals. No company will at any point need to run a promotion if there wasn't any opposition. In Pakistan, for Chinese movies, Hollywood and Bollywood are competitors. Therefore, the Promotion of Chinese movies in Pakistan is crucial to make space in the local market. Policymakers should make an easily accessible policy for Chinese movies on social media because 63\% of Pakistani are youth (Hafeez \& Fasih, 2018) and frequently use social media and watching Indian movies on YouTube because Indian movies have free access on YouTube.

- The hurdle of language can be removed through dubbing, voiceover, or subtitle. For instance, if Chinese movies are translated into Urdu, this hurdle can be cleared. Like recently, Turkish dramas in Pakistan are on-air on PTV with Urdu voiceover. According to the national TRP (Television Rating Points), PTV is on the top among 109 satellite channels in Pakistan. In addition, PTV has more than 12 million subscribers on the YouTube channel (YouTube, 2021).

- China's film industry can collaborate with the Pakistani film industry and co-produce and/or cast artists from both countries to catch the attention and enhance the number of moviegoers. Exchange face in movies already done by the Chinese film industry with Hollywood and Bollywood. For example, in 2016, "The Great Wall" was made in China, and it was the co-production of America-England-China. According to Liu Chun, general manager of China Film Co-production Corporation, China has co-production agreements with 
22 countries, including the United Kingdom, France, Russia, New Zealand, Japan, and India (Rui, 2020). In the future, China film cooperation can also sign an agreement with the Pakistan film industry for co-production through which both countries overcome cultural differences.

- China's film industry can use new technology in their movies like Hollywood to attract moviegoers in Pakistan. One of the best examples is the Hollywood action movie "The Fate of The Furious or Fast 8", an action movie that is the highest-grossing Hollywood film in Pakistan.

- Movies should be included some comedy related to Pakistani culture for the Pakistani viewers. For example, through humor, Chinese movies can attract moviegoers in Pakistan.

- In Pakistan, many beautiful and historical places could be better for shooting movies; China film industry should make a movie in Pakistan; in this way, more and more people can be interested in watching that movie because of psychological attachment.

- China and Pakistan enjoy more than 70 years of friendship in the region china can make a documentary film in this era and present for the Pakistan people. This is the best way for Pakistani people and the Chinese people to understand each other.

- The Chinese people in Pakistan are more than 50,000 (Ministry of Foreign Affairs, 2021), working in different sectors. They cannot come to China, and research says that most Chinese like to go to the cinema to watch Chinese movies; screening Chinese movies in Pakistan will also allow them to watch Chinese movies. Through film industries, both countries will be closer than ever before.

- According to Reuters, 25,000 Pakistani are learning the Chinese language in their homes, while more than 22,000 students learn the Chinese language in China (Nadeem, 2019). In 2019, more than 28,000 Pakistani students were studying in different Chinese universities. The population of students is increasing year by year because of a series of particular policies offered by the Chinese government for Pakistan; after the CPEC launch, a Belt and Road Initiative pilot project. As a result, official data shows that China has become the top education destination for Pakistani students. Based on these statistics, we can say that Chinese movies have a bright future in Pakistan (China Admission, 2019).

\section{Conclusion}

Pakistan and China are enjoying friendship since both countries came into being. And both countries cooperate in different sectors, but entertainment industries lack cooperation; therefore, the primary purpose of this review is to find out why Chinese movies are not screened in Pakistan, which could be a booming market for Chinese film in the future. In this review, we discussed some reasons behind this failure, which could open doors for Chinese movies in Pakistan once overcome. In addition, suggestions are recommended for the Chinese films in 
the Pakistani market for screening, which could benefit both countries.

\section{Acknowledgements}

Author Zakir Ullah acknowledges the support of the Chinese Scholarship Council for their financial support provided during master's studies. In addition, we are thankful to Dr. Wasim Sajjad and Dr. Ali Bahadur from Northwest Institute of Eco-Environment and Resources, CAS, Lanzhou, for their motivation and technical support to accomplish this study.

\section{Conflicts of Interest}

The authors declare no conflict of interest.

\section{References}

Blasco, P. G., Moreto, G., Blasco, M. G., Levites, M. R., \& Janaudis, M. A. (2015). Education through Movies: Improving Teaching Skills and Fostering Reflection among Students and Teachers. Journal for Learning through the Arts, 11, n1. https://doi.org/10.21977/D911122357

Champoux, J. (1999). Film as a Teaching Resource. Journal of Management Inquiry, 8, 206-217. https://doi.org/10.1177\%2F105649269982016

Gao, L., \& Qin, G. (2020). Comparative Study of National Cultures in Chinese and Japanese Films. In International Conference on Education, Management, Computer and Society (pp. 210-215). Scholar Publishing Group.

Hafeez, E., \& Fasih, T. (2018). Growing Population of Pakistani Youth: A Ticking Time Bomb or a Demographic Dividend. Journal of Education and Educational Development, 5, 211-226. https://doi.org/10.22555/joeed.v5i2.2022

Hoskins, C., \& Finn, A. (1998). Global Television and Film: An Introduction to the Economics of the Business. Oxford University Press.

Reuters Staff (2008, April 14). Pakistan's Musharraf Pushes for China Oil Pipeline. Reuters. https://www.reuters.com/article/us-china-pakistan-idUSPEK19665820080414

Samaa Staff (2019, March 10). Pakistan Is China's 'Iron Brother', Says Chinese Foreign Minister Wang Yi.

https://www.samaa.tv/news/2019/03/pakistan-is-chinas-iron-brother-says-chinese-fore ign-minister-wang-yi/

Nadeem, M. (2019, September 11). China Boosts Soft Power in Pakistan via Film and Social Media. Reuters.

https://www.reuters.com/article/us-china-silkroad-pakistan-softpower-idUSKCN1VW OLJ

Wikipedia (2021, April 4). List of Highest-Grossing Films in Pakistan. https://en.wikipedia.org/wiki/List_of_highest-grossing_films_in_Pakistan

PR Newswire (2021, April 1). IMAX Stomps to Biggest Domestic Opening in over a Year with \$4.5 Million for “Godzilla vs. Kong”. PR Newswire. https://www.prnewswire.com/news-releases/imax-stomps-to-biggest-domestic-openin g-in-over-a-year-with-4-5-million-for-godzilla-vs-kong-301261764.html

Brzeski, P. (2020, October 7). China, the World's Second-Largest Film Market, Moves beyond Hollywood. The Hollywood Reporter.

https://www.hollywoodreporter.com/news/china-the-worlds-second-largest-film-mark et-moves-beyond-hollywood 
Shackleton, L. (2018, March 22). "The Foreigner": Anatomy of a Successful UK-China Co-Production. Screendaily.

https://www.screendaily.com/features/the-foreigner-anatomy-of-a-successful-uk-china -co-production/5127695.article

YouTube (2021, April 19). Turkish Radio and Television (TRT). https://www.youtube.com/channel/UCfiM9_Me5QJBEr0PItkbXgw

Rui, Z. (2020, August 29). China Has Made 1,127 Film Co-Productions since 1979. http://www.china.org.cn/arts/2020-08/29/content_76649376.htm

Ministry of Foreign Affairs (2021, March 30). http://mofa.gov.pk/

China Admission (2019, September 8). Pakistani Students in China. https://www.china-admissions.com/pakistani-students-in-china/

Reuters Staff (2020/08/06). Pakistan Approves Most Expensive China-Aided Project to Date. https://www.reuters.com/article/pakistan-china-cpec-railway-idUSL4N2F740A

Address at Islamabad Convention Centre (2006, November 24). Carry on Traditional Friendship and Deepen All-Round Cooperation.

http://pk.chineseembassy.org/eng/svhjt/t282196.htm

Khan, A. W., Adnan, M., Hussain, S., \& Tariq, M. (2015). Decline of Film Industry in Pakistan Causes and Future Prospects. International Journal in IT \& Engineering, 3, 1-22.

Summerfield, E. (1993). Crossing Cultures through Film. Intercultural Press.

Rao, S.-G. (2012). Films and National Image: Industry, Culture and Aesthetics. Journal of Shanghai University (Social Sciences Edition), 29, 16-30.

The Economic Times (2019, October 9). Pakistan-China Friendship Unbreakable, Rock-Solid: $X i$.

https://economictimes.indiatimes.com/news/international/world-news/pakistan-chinafriendship-unbreakable-rock-solid-xi/articleshow/71503447.cms?from $=\mathrm{mdr}$ 